Harrison, B. D. \& Nixon, H. L. (1959). J. gen. Microbiol. 21, 569-581

\title{
Separation and Properties of Particles of Tobacco Rattle Virus with Different Lengths
}

\author{
By B. D. HARRISON AND H. L. NIXON \\ Rothamsted Experimental Station, Harpenden, Hertfordshire
}

\begin{abstract}
SUMMARY: Tobacco rattle virus was isolated from tobacco sap by differential centrifugation; the yield was about $50 \mathrm{mg}$. virus/l. sap. Purified preparations were

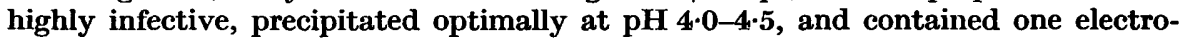
phoretic component; chemical analysis and the ultraviolet absorption spectrum suggest they contain about $5 \%$ nucleic acid and $95 \%$ protein. Most rod-shaped particles in purified preparations were $73-77 \mathrm{~m} \mu$ or $179-192 \mathrm{~m} \mu$ long: all were $25 \mathrm{~m} \mu$ wide. These two components were separated by rate zonal centrifugation in sucrose density-gradient solutions: both have the same density in solution as tobacco mosaic virus, and they have sedimentation constants of about $198 \mathrm{~s}$ and $295 \mathrm{~s}$, respectively. No differences were found between long and short particles in serological behaviour, electrophoretic mobility or ultraviolet absorption spectrum; apparently they differ little in gross chemical composition. Only the long particles are infective. Particles slightly shorter than $179 \mathrm{~m} \mu$ seem non-infective; some of these may be aggregates of two short ones. Short particles rarely aggregate end-to-end at $\mathrm{pH} \mathrm{6.8}$ $7 \cdot 0$ but aggregation increases as the $\mathrm{pH}$ value decreases.
\end{abstract}

Although tobacco rattle virus has been known for many years, occurs in many countries and has an extremely wide host range, only few of its intrinsic properties have been described. Among these, the rod-like shape (van der Want \& Rozendaal, 1948; Paul \& Bode, 1955), large temperature coefficient of thermal inactivation, stability in plant sap and failure to show photoreactivation (Cadman \& Harrison, 1959), suggest similarities to tobacco mosaic virus; but the different dimensions of the virus particles and their lack of common antigens show that the two viruses are unrelated. The properties of purified preparations of tobacco rattle virus, described in the first part of this paper, give further evidence of similarity to tobacco mosaic virus. But unlike tobacco mosaic virus, and many other viruses with elongated particles, the lengths of particles of tobacco rattle virus fall into two major categories (Paul \& Bode, 1955); the length of the longer particle is not a simple multiple of that of the shorter. The separation and properties of these two kinds of particle are described in the second part of this paper.

\section{ME'THODS}

The PRN isolate of tobacco rattle virus (TRV; Cadman \& Harrison, 1959) was cultured in the inoculated leaves of White Burley tobacco (Nicotiana tabacum L.). Leaves with confluent lesions were macerated, the sap squeezed through muslin and stored at $-20^{\circ}$. Infectivity was assayed by comparing the numbers of local lesions produced by different inocula in the primary leaves of French bean (Phaseolus vulgaris L. var. Prince) or in leaves of 
Chenopodium amaranticolor Coste \& Reyn. 'Super-floss Celite' powder (Johns-Manville Ltd.) was mixed with all inocula. Antiserum was produced by injecting a rabbit intravenously, initially with $3 \mathrm{mg}$. purified virus, and a month later with $4 \mathrm{mg}$.; the rabbit was bled 10 days after the second injection.

Electrophoretic measurements were made in a model $38 \mathrm{~A}$ Perkin-Elmer apparatus with the Philpot-Svenson optical system, at a potential gradient of $9 \cdot 5 \mathrm{~V} . / \mathrm{cm}$.

For centrifugation in sucrose density-gradients (Brakke, 1953), plastic tubes of $50 \times 12 \mathrm{~mm}$. were used. Each density gradient was made from three sucrose solutions, usually 67,134 and $200 \mathrm{~g}$./l., but gradients made from 134, 200 and 267 g./l., 200, 267 and 334 g./l., or 267,334 and 400 g./l., were also used: all sucrose solutions contained $0.033 \mathrm{M}(\mathrm{pH} \mathrm{7.0)}$ phosphate buffer and were stored at $5^{\circ}$. Density-gradient preparations were made by pipetting $1.5 \mathrm{ml}$. of the least dense solution into a tube, then introducing $1.5 \mathrm{ml}$. of the solution of intermediate density at the bottom of the tube by using a Pasteur pipette, and finally, $1.0 \mathrm{ml}$. of the densest solution was similarly introduced below the other two. The density-gradient preparations were kept overnight at $5^{\circ}$ before centrifuging in the no. 4 swing-out head of an MSE 'Super-speed 25' refrigerated centrifuge. Both centrifuge rotor and virus preparation were also cooled to $5^{\circ}$ before use; immediately before centrifugation, $0.4-0.5 \mathrm{ml}$. virus preparation was floated on each density-gradient mixture. After centrifugation the temperature of the liquid was $5-8^{\circ}$. At $16,000 \mathrm{rev} . / \mathrm{min}$., the speed usually used, the centrifugal force was $20,400 \mathrm{~g}$ at the top of the column of liquid and $31,700 \mathrm{~g}$ at the bottom. The centrifuged density-gradient preparations were viewed in a vertical beam of light against a dark background and samples of 0.2-0.4 ml. removed by carefully lowering to the required depth a Pasteur pipette whose tip was bent through an. angle of $90^{\circ}$. The samples were dialysed overnight at room temperature against $0 \cdot 1 \mathrm{M}$-ammonium acetate at $\mathrm{pH} 6 \cdot 8$, and assayed for infectivity and particle content.

The concentration of virus particles was estimated by a spray-droplet technique (Nixon \& Fisher, 1958). One vol. dialysed sample was mixed with 1 vol. $0 \cdot 1 \%$ bovine serum albumin and 1 vol. standard latex suspension (Dow Chemical Co.; particles designated $88 \mathrm{~m} \mu$ diameter by the makers). The mixture was sprayed on to electron microscope grids, which were examined with a Siemens Elmiskop I microscope and the different types of particles in the droplet traces counted on the fluorescent screen. Estimates of virus content made by the spray-droplet method, when converted to mg./l., were only $\mathbf{7 8} \%$ of the values indicated by dry-weight determinations or calculated from nitrogen analyses. The difference probably resulted from an overestimate of the mean diameter, and hence the weight, of the latex particles in the standard suspension (Nixon \& Fisher, 1958). No allowance for this discrepancy was made in the counts of virus particles given below. 


\section{Fractionation of tobacco rattle virus}

\section{RESULTS}

\section{Method of concentrating tobacco rattle virus}

Tobacco rattle virus is stable and readily concentrated; differential centrifugation was the method finally adopted. Infective tobacco sap, stored at $-20^{\circ}$ for at least a month, was thawed and centrifuged for $3 \mathrm{~min}$. at $9000 \mathrm{~g}$, when the clear supernatant fluid was decanted and centrifuged for $90 \mathrm{~min}$. at $75000 \mathrm{~g}$. The resulting pellet was resuspended in $\mathrm{pH} 7 \cdot 5$ borate buffer or $\mathrm{pH} 6 \cdot 4$ citrate buffer of one-tenth the original volume. After this suspension had been taken through a second cycle of low- and high-speed centrifugation, the translucent faintly coloured pellet was resuspended in $\mathrm{pH} 6 \cdot 4$ citrate buffer of one-twentieth the original volume of sap and centrifuged at low speed. The supernatant fluid was kept at $20^{\circ}$ for 2-3 days before centrifuging for $120 \mathrm{~min}$. at $57000 \mathrm{~g}$; the colourless translucent pellet was resuspended in citrate buffer, centrifuged at low speed, and the resulting supernatant fluid was the final preparation. The final preparations contained 0.5-2.0 $\mathrm{mg}$. virus $/ \mathrm{ml}$., indicating a virus concentration in sap of about $50 \mathrm{mg}$./l.; these are referred to below as 'purified preparations'. When needed for injecting rabbits, pellets from the last high-speed centrifugation were suspended in $0.85 \%$ sodium chloride solution; preparations used for density-gradient centrifugation were made by only two cycles of high- and low-speed centrifugation and the final pellets were suspended in $0.033 \mathrm{M}$-phosphate buffer $(\mathrm{pH} \mathrm{7.0)}$ ).

\section{Properties of purified preparations of tobacco rattle virus}

Purified preparations were slightly opalescent at $100 \mathrm{mg} . / \mathrm{l}$. but even at $2000 \mathrm{mg}$./1. solutions did not show anisotropy of flow when rocked in narrow tubes between crossed polarizers; they were infective when diluted to $0.01 \mathrm{mg}$./1. but not at $0.001 \mathrm{mg} . / \mathrm{l}$. With virus antiserum, they precipitated specifically down to $2-5 \mathrm{mg}$./1.; there was only one optimal precipitation zone. They did not precipitate with tobacco mosaic virus antiserum, and tobacco mosaic virus did not precipitate with tobacco rattle virus antiserum.

Electrophoretic behaviour. When examined electrophoretically, preparations containing $1 \mathrm{mg}$. virus $/ \mathrm{ml}$. showed one tall slender peak, with a mobility of $-1.7 \times 10^{-5} \mathrm{~cm} .^{2} \mathrm{sec} .^{-1} \mathrm{~V} .^{-1}$ in $0.067 \mathrm{M}$-phosphate buffer ( $\mathrm{pH} 7 \cdot 0$ ), only a fifth of the value for tobacco mosaic virus under the same conditions. After electrophoresis had gone on for an hour, there was still only one peak, but it had broadened more than the peak given by tobacco mosaic virus, presumably because tobacco rattle virus diffuses more rapidly.

Chemical composition. Chemical analyses were made by Miss M. Byers and Dr W. S. Pierpoint. Nitrogen was determined by a micro-Kjeldahl method, total phosphorus by the method described by Holden \& Pirie (1955), and carbohydrate (using a ribose standard) by an orcin method. The purified preparations contained about $16.5 \% \mathrm{~N}, 0.42 \% \mathrm{P}$ and $2.8 \%$ carbohydrate, values which are consistent with the composition of a nucleoprotein containing $5 \%$ nucleic acid and $95 \%$ protein. 
Ultraviolet absorption spectrum. The ultraviolet absorption curve of tobacco rattle virus closely resembled that of tobacco mosaic virus.

Precipitation in acid solutions. Like tobacco mosaic virus, tobacco rattle virus precipitates when virus preparations are acidified. Thus, when samples of a tobacco rattle virus preparation were suspended in citrate buffers of various $\mathrm{pH}$ values, precipitation was heaviest at $\mathrm{pH} \mathrm{4.0-4.5}$ (Table 1). The precipitate produced at $\mathrm{pH} 4.5$ was infective, though less so than control preparations not acidified. At $\mathrm{pH}$ values below 4.5 the particles were disrupted and no rods were found by electron microscopy in samples adjusted to pH $3 \cdot 8$. The infectivity of the virus in sap is similarly affected by acid (Cadman \& Harrison, 1959). Tobacco rattle virus precipitates when dialysed against distilled water of $\mathrm{pH} 4 \cdot 5$, a value reached when carbon dioxide is absorbed from the air during storage: the precipitates dissolve when dialysed against freshly boiled water, with a $\mathrm{pH}$ of $6 \cdot 5-7 \cdot 0$.

\section{Table 1. Effect of $\mathrm{pH}$ value on precipitation of tobacco rattle virus}

Samples $(0.1 \mathrm{ml}$.) of a purified virus preparation were mixed with $0.4 \mathrm{ml}$. citric acid/sodium hydroxide/hydrochloric acid buffer solutions. The mixtures were observed for $\mathbf{3 0}$ min., then centrifuged for $3 \mathrm{~min}$. at $9000 \mathrm{~g}$, and the infectivity of the supernatant fluids and resuspended sediments assayed after readjusting all samples to $\mathrm{pH} 7 \cdot 0$ and $2.5 \mathrm{ml}$.

\begin{tabular}{lccl} 
& \multicolumn{3}{c}{} \\
pH & $\overbrace{\begin{array}{c}\text { Supernatant } \\
\text { fluid }\end{array}}^{\text {Infectivity* of }}$ & $\begin{array}{c}\text { Resuspended } \\
\text { sediment }\end{array}$ & Amount of precipitation \\
$2 \cdot 0$ & 0 & 0 & Trace \\
$3 \cdot 0$ & 0 & 0.6 & Slight \\
$4 \cdot 0$ & $0 \cdot 2$ & 1 & Great (small floccules) \\
4.5 & 13 & 160 & Great (larger floccules) \\
$5 \cdot 0$ & 326 & 45 & Moderate \\
$7 \cdot 0$ & 1000 & 192 & 0
\end{tabular}

* Assayed on French bean; figures are relative to supernatant fluid at pH $7 \cdot 0(=1000)$ :

Electron microscopy. Purified tobacco rattle virus preparations contain rodshaped particles of various lengths, which when viewed end-on appear to have a hollow centre (Pl. 1, fig. 2). All lengths from 25 to $200 \mathrm{~m} \mu$, occur, but the lengths of most particles fall into two categories (Fig. 1). Critical measurements, made by examining electron micrographs with an optical microscope, showed the two categories to be 73-77 $\mathrm{m} \mu$ and $179-192 \mathrm{~m} \mu$ respectively. The average values, 75 and $185 \mathrm{~m} \mu$, agree well with those of 70 and $180 \mathrm{~m} \mu$ given by Paul \& Bode (1955), and confirm that the length of the longer particles is not a simple multiple of that of the shorter ones. Figure 1 also shows that the proportions of particles of different lengths originally present in frozen sap were not altered much by the purification processes. The proportions of particles of different lengths were the same when preparations were suspended in $\mathrm{pH} \mathrm{7.0-}$ 8.0 borate or phosphate buffers, or in $\mathrm{pH} 6.8$ ammonium acetate. The width of all rods was about $25 \mathrm{~m} \mu$, but great accuracy cannot be claimed for measurements of this magnitude made on shadowed preparations. If the density of tobacco rattle virus is assumed to be $\mathbf{1 \cdot 3 3}$, the average value given for tobacco 
mosaic virus by Bawden \& Pirie (1937; the density of tobacco rattle virus in solution is the same as that of tobacco mosaic virus), the longer particles have an average mass equivalent to a molecular weight of $72 \cdot 7 \times 10^{6}$, and the shorter particles of $29.5 \times 10^{6}$.

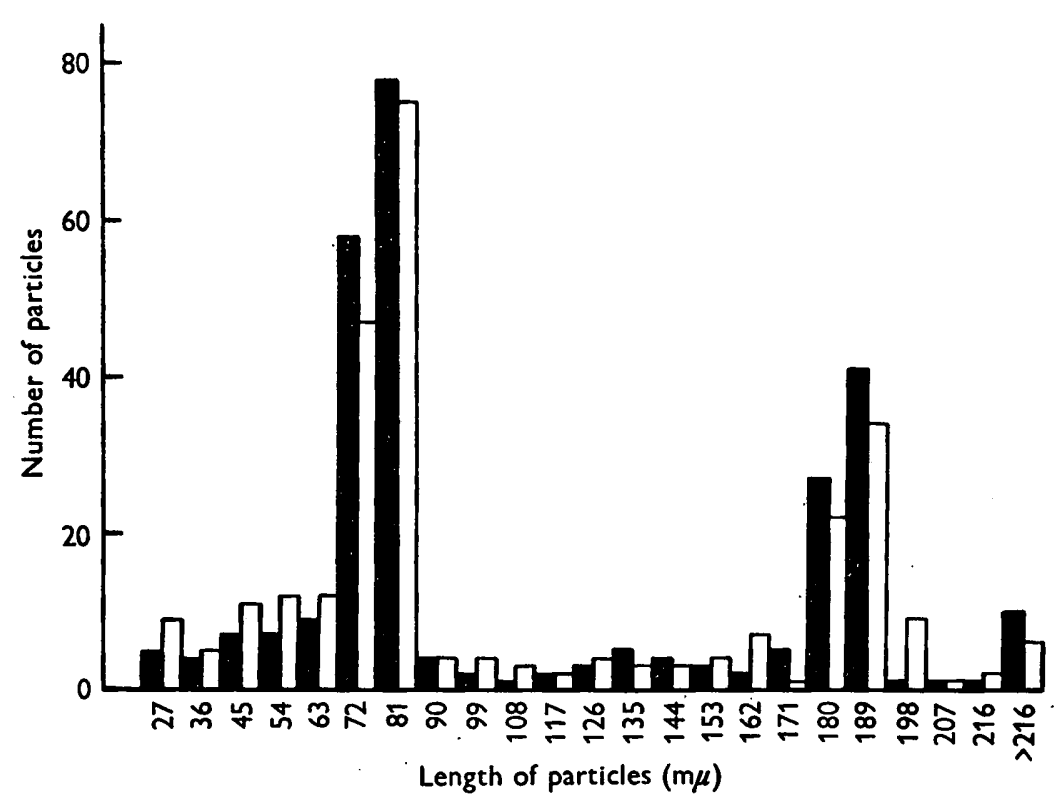

Fig. 1. Proportions of tobacco rattle virus particles of different lengths in tobacco sap after freezing (black columns) and after subsequent purification (white columns). Particle lengths are divided into categories of $9 \mathrm{~m} \mu$.

\section{Separation and properties of long and short particles}

The longer particles of tobacco rattle virus are about 2.5 times as long as the shorter ones and are clearly not aggregates of them. It therefore seemed of interest to separate the two kinds of particles and compare their properties.

Separation and infectivity of long and short particles. Differential ultracentrifugation did not give a useful fractionation, but centrifuging purified preparations of tobacco rattle virus in sucrose density-gradients produced two opalescent zones. The top of the upper one was clearly defined, but the top of the lower one was not; the upper zone was usually broader than the lower, and both were narrower than the virus preparation initially floated on the densitygradient (Pl. 1, fig. 1). Table 2 shows the infectivity and the number of long and short particles in samples from above, below, and the middle of, each zone. For convenience, particles twice or more as long as the commonest type of short particles were counted as 'long particles' and the rest as 'short particles'. Short particles were most concentrated in the top zone and long particles were mostly in the bottom zone. The relative thicknesses and amounts of opalescence of the two zones therefore depended on the ratio of long to short particles in the unfractionated purified preparation. This ratio has varied 
from $1: 2$ to $1: 18$ in different preparations; the cause of the variations is unknown. Thus, whereas the top zone was always obvious, the bottom zone was often too indistinct for its depth to be measured accurately.

Table 2 also shows that specific infectivity increases with depth of sampling and that the relative infectivity of the samples was proportional to the number of long particles they contained. Indeed, the ratio of the concentration of long particles to relative infectivity was remarkably constant, and the similarity of the ratios for the samples from the density-gradients to those for the unfractionated preparations shows that little or no infectivity was lost during the centrifugation procedures. The relative infectivity of the samples was the same for tobacco or Chenopodium amaranticolor as for French bean. The short particles seemed to be non-infective.

\section{Table 2. Separation of two components of tobacco rattle virus preparations} by centrifuging in a sucrose density-gradient

Purified virus preparation $(0.4 \mathrm{ml}$.) was floated on density-gradients made from $1.5 \mathrm{ml}$. $67 \mathrm{~g} .1 \mathrm{l} ., 1.5 \mathrm{ml}$. $134 \mathrm{~g}$. $/ \mathrm{l}$. and $1.0 \mathrm{ml} .200 \mathrm{~g}$. $/ \mathrm{l}$. sucrose solutions. After $2 \mathrm{hr}$. centrifugation at 16,000-17,000 rev./min., samples were removed, diluted $1 / 4$ with water, dialysed overnight against $0.1 \mathrm{~m}$-ammonium acetate and assayed for infectivity and particle content. Unfractionated samples, diluted $1 / 10$ with water, were also dialysed and assayed.

\begin{tabular}{|c|c|c|c|c|c|}
\hline \multirow{2}{*}{$\begin{array}{c}\text { Depth } \\
\text { sampled } \\
\text { (mm.) }\end{array}$} & \multicolumn{2}{|c|}{ Virus particles/ml. $\left(\times 10^{8}\right)^{*}$} & \multirow{2}{*}{$\begin{array}{c}\text { Relative } \\
\text { infectivity } \dagger\end{array}$} & \multirow{2}{*}{$\begin{array}{l}\text { Ratio of no. } \\
\text { long particles } \\
\left(\times 10^{8}\right): \\
\text { relative } \\
\text { infectivity }\end{array}$} & \multirow{2}{*}{$\begin{array}{c}\text { Specific } \\
\text { infectivity } \\
\text { (lesions/ } / \mu \mathrm{g} . \\
\text { virus) }\end{array}$} \\
\hline & Long & Short & & & \\
\hline \multicolumn{6}{|c|}{ Expt. 1 (16,000 rev./min.) } \\
\hline $12-15$ & 0 & 4 & $\mathbf{0}$ & - & 0 \\
\hline $17-19 \ddagger$ & $\mathbf{0}$ & 7,600 & 1 & - & 0.04 \\
\hline $21-23$ & 789 & $\mathbf{3 , 2 0 0}$ & 597 & $1 \cdot 2$ & $34 \cdot 0$ \\
\hline $24-26 \ddagger$ & 1,920 & 1,080 & 1,183 & $\mathbf{1} \cdot \mathbf{6}$ & $58 \cdot 0$ \\
\hline 28-30 & 368 & 96 & 302 & 1.2 & $86 \cdot 0$ \\
\hline Unfraction- & 2,720 & 7,600 & 1,770 & 1.5 & $39 \cdot 0$ \\
\hline \multicolumn{6}{|c|}{ Expt. 2 (17,000 rev./min.) } \\
\hline $14-17$ & $\mathbf{5}$ & 11 & 1 & $\mathbf{5} \cdot \mathbf{0}$ & $12 \cdot 0$ \\
\hline $20-22 \ddagger$ & 173 & 4,740 & 2 & $86 \cdot 5$ & $\mathbf{0} \cdot \mathbf{1}$ \\
\hline $23-25$ & 110 & $\mathbf{5 , 0 4 0}$ & 6 & $18 \cdot 3$ & $\mathbf{0 \cdot 3}$ \\
\hline $26-28 \ddagger$ & 2,300 & $\mathbf{1 , 5 4 0}$ & 996 & $2 \cdot 3$ & $39 \cdot 0$ \\
\hline $30-32$ & 1,540 & 685 & 620 & $2 \cdot 5$ & 40.0 \\
\hline $\begin{array}{l}\text { Unfraction- } \\
\text { ated }\end{array}$ & $\mathbf{3 , 6 5 0}$ & 10,960 & 1,611 & $\mathbf{2 \cdot 3}$ & $23 \cdot 0$ \\
\hline
\end{tabular}

The long and short particles were not completely separated in one centrifugation, and could be fractionated further by again centrifuging either top or bottom zones (Table 3). After the second centrifugation, samples from the top zone were almost non-infective, and contained very few long particles (Fig. 2; Pl. 1, fig. 4). Moreover, of those counted as 'long' in spray-droplet assays, most were in the range $140-170 \mathrm{~m} \mu$. There is no evidence, however, 
that particles 140-170 $\mathrm{m} \mu$ in length were infective, and indeed they were probably not, for samples in which they formed a large proportion of the long particles counted were much less infective than samples containing a similar number of particles over $170 \mathrm{~m} \mu$ in length. Examples of samples containing particles of 140-170 $\mathrm{m} \mu$ are those from 20-22 mm. and 23-25 mm. in Expt. 2,

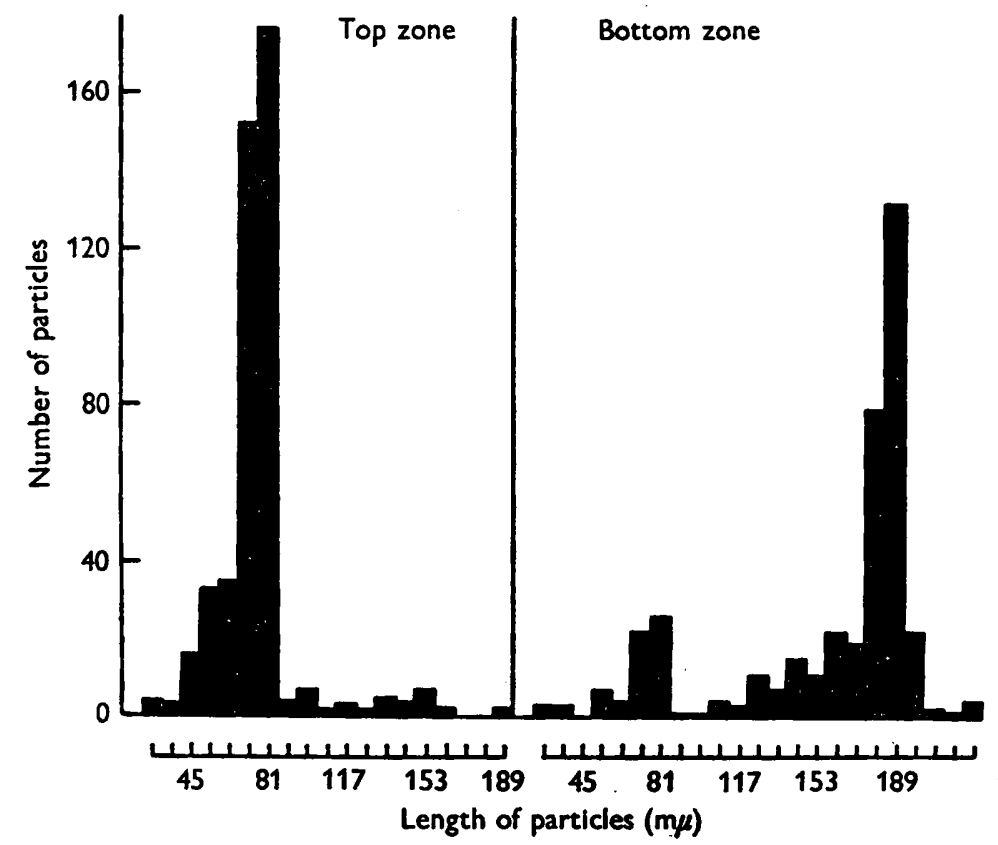

Fig. 2. Proportions of tobacco rattle virus particles of different lengths in a sample from (left) the top, and (right) the bottom opalescent zone after two centrifugations in a sucrose density-gradient. Particle lengths are divided into categories of $9 \mathrm{~m} \mu$. The last column in the right-hand diagram represents all particles longer than $216 \mathrm{~m} \mu$.

Table 3. Separation of infective and non-infective particles of tobacco rattle virus by two cycles of centrifugation in a sucrose density-gradient

Preparation of density-gradients, centrifugation and assays were done as described in Table 2.

\begin{tabular}{|c|c|c|c|}
\hline Sample from & $\begin{array}{c}\text { Relative } \\
\text { infectivity }\end{array}$ & $\begin{array}{l}\text { Virus content } \\
\quad(\mathrm{mg} . / \mathrm{l} .)\end{array}$ & $\begin{array}{c}\text { infectivity } \\
\text { (lesions/ } \mu \mathrm{g} \\
\text { virus) }\end{array}$ \\
\hline $\begin{array}{l}\text { Top zone, } \\
\text { first gradient }\end{array}$ & $9 \cdot 5$ & 192 & 0.05 \\
\hline $\begin{array}{l}\text { Top zone, } \\
\text { second gradient }\end{array}$ & 0.5 & 36 & 0.014 \\
\hline $\begin{array}{l}\text { Bottom zone, } \\
\text { first gradient }\end{array}$ & 1840 & 103 & $17 \cdot 9$ \\
\hline $\begin{array}{l}\text { Bottom zone, } \\
\text { second gradient }\end{array}$ & 881 & 36 & $24 \cdot 5$ \\
\hline $\begin{array}{l}\text { Unfractionated } \\
\text { preparation, } \\
\text { diluted } 1 / 10\end{array}$ & 898 & 111 & $8 \cdot 1$ \\
\hline
\end{tabular}


Table 2; the possibility that these particles were aggregates of two short ones is discussed further below.

Although preparations containing only short particles were obtained by recentrifuging samples from the top zone, preparations of long particles always contained some short ones(Fig. $2 ; \mathrm{Pl} .1$, fig. 3). This was probably because a few long particles, perhaps initially aggregates of short ones, fragmented during or after centrifugation.

Sedimentation rates. Using Brakke's (1958) methods and tobacco mosaic virus as a standard, the sedimentation rates of the two common kinds of tobacco rattle virus particles were estimated. In the first method, densitygradients were made from solutions of 67,134 and $200 \mathrm{~g}$. sucrose/1.; purified tobacco rattle virus was added to some tubes and purified tobacco mosaic virus to others. The tubes were then centrifuged for different periods at $16,000 \mathrm{rev} . / \mathrm{min}$. and the depths of the tops of the opalescent zones measured. After applying a correction for the times taken by the centrifuge to accelerate and decelerate, the lines obtained by plotting depth of zone against time were almost straight, both with tobacco mosaic virus and with each tobacco rattle virus zone. The times taken to reach an arbitrary depth $(15 \mathrm{~mm}$.) were determined graphically and, assuming their reciprocals to be in the ratios of their sedimentation constants (Brakke, 1958), particles in the top zone of tobacco rattle virus were calculated to have a constant 1.06 times, and those in the bottom zone $\mathbf{1 \cdot 6 6}$ times, that of tobacco mosaic virus.

This method works well only when the density of the viruses compared is the same. In the second method, both densities and sedimentation constants were determined. The sedimentation rates of the tobacco rattle virus zones were compared with that of tobacco mosaic virus in sucrose gradients covering a wide range of densities: Using these results and the formula given by Brakke (1958), and assuming the density of tobacco mosaic virus in solution to be 1.27 (Schachman \& Lauffer, 1949), Fig. 3 was plotted. Although there were fewer reliable points for the bottom zone than for the top, Fig. 3 shows that the particles in each zone had a density of about $1 \cdot 27$, the same as that of tobacco mosaic virus. From the intercepts at $\rho^{\prime}-\rho=0$, the sedimentation constants of the particles in the two tobacco rattle virus zones were given as $\mathbf{1 . 0 6}$ and 1.58 times that of tobacco mosaic virus. If the latter value is taken to be $187 \mathrm{~s}$ (Lauffer, 1944), the values for the long and short particles of tobacco rattle virus are $295 \mathrm{~s}$ and $198 \mathrm{~s}$, respectively.

Serological tests and ultraviolet absorption spectra. Table 4 shows some properties of a sample from the top zone of a density gradient and of one from a recentrifuged bottom-zone: in the first sample, $94 \%$ by weight of the material was short particles, and in the second, $88 \%$ was long particles. The concentration in both samples was similar and both precipitated to similar end-points with antiserum to unfractionated tobacco rattle virus. The serological precipitates formed by the two samples appeared to be very similar, and were of the somatic type. The ultraviolet absorption spectra $(230-300 \mathrm{~m} \mu)$ of the two samples were almost identical, evidence that both long and short particles are nucleoproteins of similar gross composition. 
In further experiments on the antigenic constitution of long and short particles, gel-diffusion tests were made on slides (Mansi, 1958). Preparations of short particles and unfractionated virus preparations each produced one line of precipitation with virus antiserum, and the two lines joined. Absorption

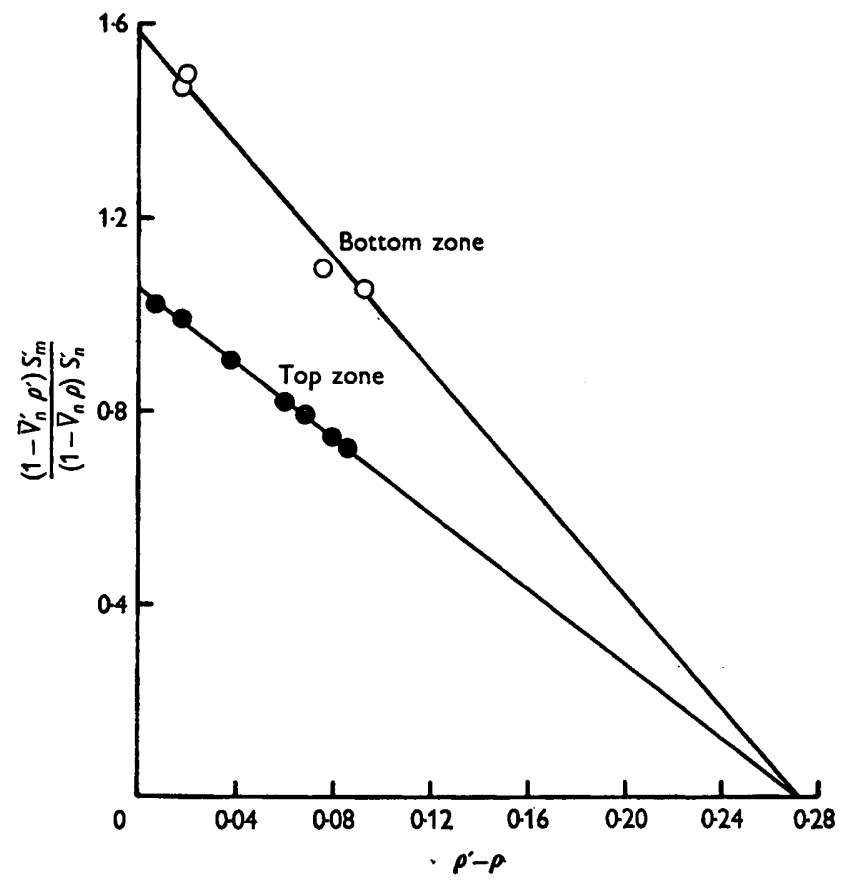

Fig. 3. Diagram of the sedimentation rates of top and bottom zones of tobacco rattle virus in sucrose density-gradients relative to that of tobacco mosaic virus. $\bar{V}_{n}=\bar{V}_{n}^{\prime}=$ partial specific volume of tobacco mosaic virus; $S_{m}^{\prime} / S_{n}^{\prime}=$ ratio of the sedimentation rate of the tobacco rattle virus zone to that of tobacco mosaic virus; $\rho=$ density of water at $20^{\circ}$; $\rho^{\prime}=$ density of sucrose solution at half the depth reached by the tobacco rattle virus zone.

Table 4. Properties of particles of tobacco rattle virus from top and bottom zones of a sucrose density-gradient

Preparation of density-gradients, centrifugation, infectivity tests and particle counts were done as indicated in Table 2.

Depth (mm.)

Long particles $/ \mathrm{ml} .\left(\times 10^{8}\right)$

Short particles $/ \mathrm{ml}$. $\left(\times \mathbf{1 0}^{8}\right)$

Relative infectivity*

Ratio of no. long particles

$\left(\times 10^{8}\right)$ : relative infectivity

E260/E280

Serological precipitation

end-point

Virus content (mg./l.)
Sample from

$\begin{array}{cc}\text { Top zone } & \text { Bottom zone } \\ 15-17 & 21-23 \\ 158 & 2400 \\ 6560 & 816 \\ 23 & 462 \\ 6 \cdot 9 & 5 \cdot 2 \\ 1 \cdot 11 & 1 / 8 \\ 1 / 16 & 1 \cdot 10 \\ 43.2 & 42.3\end{array}$

*Assayed on Chenopodium amaranticolor. 
of antiserum with short particles abolished its ability to form a line with either short particles or unfractionated preparations. Preparations containing predominantly long particles did not form a line with antiserum, either because they were too dilute or because long particles diffused through $1 \%$ agar gel too slowly. These tests did not reveal antigenic heterogeneity, but neither did they show that long and short particles contained the same antigens. Precipitation tests in tubes were therefore made with unfractionated preparations and with samples from twice-centrifuged top and bottom zones. Ninetyseven \% of the virus in sample 'top 2' was short particles and $95 \%$ of that in sample 'bottom 2' was long particles (Table 5). Of the $3 \%$ long particles in sample 'top 2', a large proportion were non-infective and shorter than $170 \mathrm{~m} \mu$; many were probably aggregates of two short particles, so their presence does not complicate interpretation of the results. The antiserum, prepared against an unfractionated preparation, had the same titre against all three antigens, and when partially absorbed with short particles, it still had a similar, but much lower, titre against all three (Table 5). Long and short particles, therefore, have few or no antigens not possessed by each other.

Table 5. Serological behaviour of particles of tobacco rattle virus from top and bottom zones of sucrose density-gradients

Preparation of density-gradients, centrifugation and assays were done as indicated in Table 2.

(a) Composition of antigen preparations

\begin{tabular}{|c|c|c|c|c|c|}
\hline \multirow{2}{*}{$\begin{array}{c}\text { Antigen } \\
\text { preparation }\end{array}$} & \multicolumn{2}{|c|}{ Virus particles/ml. $\left(\times 10^{8}\right)$} & \multirow{2}{*}{$\begin{array}{c}\text { Relative } \\
\text { infectivity }\end{array}$} & \multirow{2}{*}{$\begin{array}{c}\text { Virus } \\
\text { concentra- } \\
\text { tion } \\
(\mathrm{mg} . / \mathrm{l} .)\end{array}$} & \multirow{2}{*}{$\begin{array}{c}\text { Specific } \\
\text { infectivity } \\
\text { (lesions/ } \\
\mu \mathrm{g} . \text { virus) }\end{array}$} \\
\hline & Long & Short & & & \\
\hline Top 2 & 208 & 17,400 & $\mathbf{3}$ & 110 & 0.03 \\
\hline Bottom 2 & 647 & 81 & 652 & $10 \cdot 3$ & $63 \cdot 2$ \\
\hline $\begin{array}{l}\text { Unfractionated, } \\
\text { diluted } 1 / 4\end{array}$ & $\mathbf{3 , 3 2 0}$ & 16,600 & 10,600 & 154 & $68 \cdot 8$ \\
\hline
\end{tabular}

(b) Precipitation end-points* of antiserum

\begin{tabular}{lcc} 
& \multicolumn{2}{c}{ Antiserum $\dagger$} \\
Antigen preparation & $\begin{array}{c}\text { Absorbed with } \\
9 \text { vol. top 2 }\end{array}$ \\
Top 2, diluted 1/2 & $1 / 160$ & $1 / 10$ \\
Bottom 2, undiluted & $1 / 160$ & $1 / 10$ \\
Unfractionated, & $1 / 160$ & $1 / 20$ \\
diluted 1/8 & \\
$*$ Recorded after 5 hr. incubation at 38 & \\
$\dagger$ & Prepared against an unfractionated virus preparation.
\end{tabular}

Aggregation of short particles. In contrast to many other viruses with elongated particles, tobacco rattle virus particles do not aggregate end-to-end much at $\mathbf{p H} 7$. Indeed, it is their failure to aggregate which allows the separation of long and short particles in sucrose density-gradients. However, as already noted, considerable numbers of particles 140-170 $\mathrm{m} \mu$ long were sometimes present in samples from the top zone of sucrose density-gradients. 


\section{Fractionation of tobacco rattle virus}

In one experiment, the proportion of such particles in a sample from the top zone increased from 16 to $59 \%$ of the total weight of virus present during 14 days' storage at $\mathrm{pH} 6.5$ and $5^{\circ}$, and as the total virus content of the sample was the same at the beginning and end of the storage period, the additional medium-length particles seem to have formed by aggregation of smaller ones.

To see whether such aggregation depends on $\mathrm{pH}$ value, portions of a sample from the top zone were dialysed against ammonium acetate/acetic acid/ ammonia mixtures of $\mathrm{pH} 5 \cdot 6,6 \cdot 4$ and $7 \cdot 2$; respectively, the resulting preparations each had a trace of infectivity. Examination of droplet traces showed that nearly all the particles were of three kinds, short, medium length (140-170 $\mathrm{m} \mu$ ) and very long (200-750 $\mathrm{m} \mu)$ types. Very long forms were common at $\mathrm{pH} 5 \cdot 6$, occasional at $\mathrm{pH} 6 \cdot 4$ and did not occur at $\mathrm{pH} 7 \cdot 2$. Medium length rods accounted for 35-50\% of the total weight of virus present in all three preparations, whereas typical short particles increased from $17 \%$ at $\mathrm{pH} 5 \cdot 6$ to $53 \%$ of the virus at $\mathrm{pH} 7 \cdot 2$. Thus, aggregation increased with decrease of $\mathrm{pH}$ value. The previous experiment showed that small particles aggregated to form ones of medium length; the present experiment suggests that both these types aggregate further to produce very long forms at $\mathrm{pH} 5 \cdot 6-6 \cdot 4$. Whether all medium-length particles are formed by aggregation of two short ones is

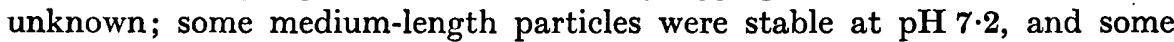
were still present after the last traces of sucrose were removed by prolonged dialysis at pH 6.8.

\section{DISCUSSION}

It is extremely difficult to draw valid conclusions from measurements of the lengths of virus particles (Pirie, 1957). Nevertheless, our results are probably free from some of the commoner sources of error. First, tobacco rattle virus particles rarely aggregate when preparations are kept for short periods at $\mathrm{pH} 7$. Secondly, the common occurrence of particles of two different lengths separated by a factor of $\mathbf{2 . 5}$ can hardly arise from selective extraction methods, as can be argued with the many other viruses which have only one common length. Thirdly, different methods of extracting tobacco rattle virus from plants give similar results; Paul \& Bode (1955) found in leaf exudate and in fresh clarified sap from different species a similar range of particle lengths, and similar proportions of long and short particles to those we describe. We therefore conclude that tobacco rattle virus has two characteristic lengths which probably occur together in the plant. By analogy, results with tobacco rattle virus support the idea that the most common, or 'normal', lengths of several other viruses in leaf exudates (e.g. Brandes \& Paul, 1957) are intrinsic properties of the viruses, are little affected by the host species and do not depend on any particular method of preparing plant extracts for electron microscopy.

Tobacco rattle virus is unusual in that the lengths of the two common types of particle differ by a factor of $2 \cdot 5$. Our admittedly crude tests suggest that the two types have a similar gross chemical composition, for they have 
the same ultraviolet absorption spectrum, the same density in solution, and mixtures of particles of the two types showed only one peak when examined electrophoretically and only one optimal zone of precipitation with virus antiserum. Also, absorption of antiserum with short particles abolished its ability to precipitate long ones. Whether the small particles are precursors or breakdown products of the larger ones, or are additional products of virusinfected cells, is unknown; but the relationship between them may not be unique among plant viruses, because purified preparations of the Rothamsted culture of tobacco necrosis virus contain nucleoprotein spheres of two sizes, and whereas the smaller particles are non-infective, infective preparations always contain the larger ones (Bawden \& Pirie, 1950).

There is some direct evidence with wheat streak mosaic virus (Brakke \& Staples, 1958) and much indirect evidence with tobacco mosaic virus (e.g. Bawden \& Pirie, 1945) that the 'normal' length is the minimum infective length. Although short particles are the most abundant ones in purified preparations of tobacco rattle virus, and they seem non-infective, our results do provide strong evidence for a minimum infective length, which is also a common one. Indeed, tobacco rattle virus particles only slightly shorter than $179 \mathrm{~m} \mu$ have little or no infectivity, and the trace of infectivity in some preparations of short particles is readily explained by the observed contamination with a few particles 179-192 $\mathrm{m} \mu$ long. It might be argued that a minute proportion of short particles is infective or that many together can infect although each alone cannot, but such arguments seem unnecessary. We have no idea what proportion of the long particles is infective; if single particles can infect, one in 100,000 would be enough to explain the observed results.

Besides those mentioned in the text, we are indebted to Dr A. Kleczkowski for making the electrophoretic measurements and to Mr R. D. Woods for technical assistance with the electron microscopy.

\section{REFERENCES}

Bawden, F. C. \& Pirie, N. W. (1937). The isolation and some properties of liquid crystalline substances from solanaceous plants infected with three strains of tobacco mosaic virus. Proc. roy. Soc. B, 123, 274.

Bawden, F. C. \& Prie, N. W. (1945). The separation and properties of tobacco mosaic virus in different states of aggregation. Brit. J. exp. Path. 26, 294.

Bawden, F. C. \& Pirie, N. W. (1950). Some factors affecting the activation of virus preparations made from tobacco leaves infected with a tobacco necrosis virus. J. gen. Microbiol. 4, 464.

Brakke, M. K. (1953). Zonal separations by density-gradient centrifugation. Arch. biochim. Biophys. 45, 275.

BrakKe, M. K. (1958). Estimation of sedimentation constants of viruses by densitygradient centrifugation. Virology, 6, 96.

BrakKe, M. K. \& Staples, R. (1958). Correlation of rod length with infectivity of wheat streak mosaic virus. Virology, 6, 14.

Brandes, J. \& PaUl, H. L. (1957). Das Elektronenmikroskop als Hilfsmittel bei der Diagnose pflanzlicher Virosen. Betrachtungen zur Vermessung faden- und stäbchenförmiger Virusteilchen. Arch. Mikrobiol. 26, 358. 
Journal of General Microbiology, Vol. 21, No. 3
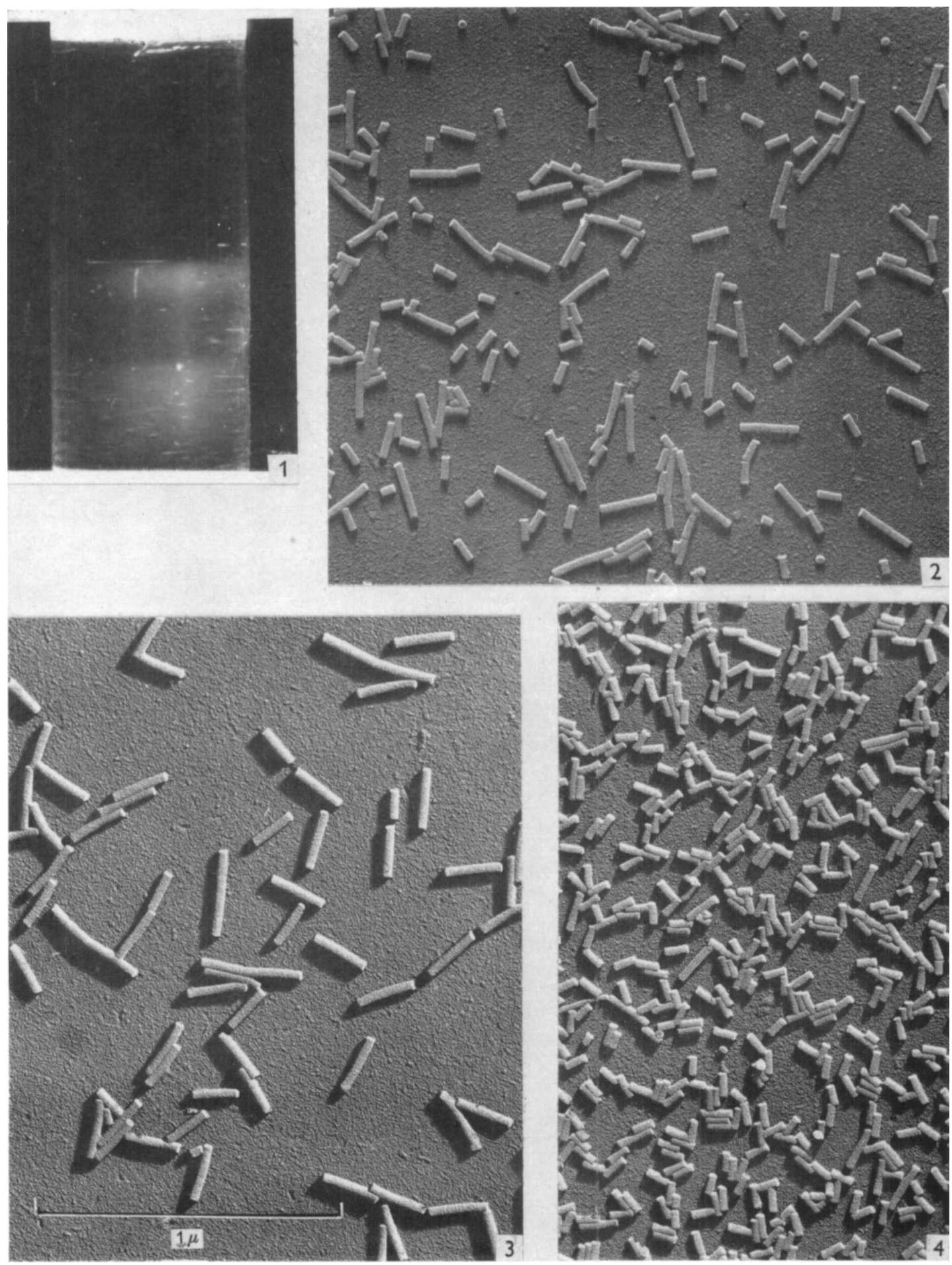

B. D. Harmison \& H. L. Nixon-Fracionation of tobacco rattle virus. Prate 1 
Cadman, C. H. \& Harrison, B. D. (1959). Studies on the properties of soil-borne viruses of the tobacco-rattle type occurring in Scotland. Ann. appl. Biol. 47, 542.

Holden, M. \& Pirie, N. W. (1955). A comparison of leaf and pancreatic ribonuclease. Biochem. J. 60, 53.

LAUFFER, M. A. (1944). The influence of concentration upon the sedimentation rate of tobacco mosaic virus. J. Amer. chem. Soc. 66, 1195.

MaNsI, W. (1958). Slide gel diffusion precipitin test. Nature, Lond. 181, 1289.

Nixon, H. L. \& Fisher, H. L. (1958). An improved spray droplet technique for quantitative electron microscopy. Brit. J. appl. Phys. 9, 68.

PaUl, H. L. \& Bode, O. (1955). Elektronenmikroskopische Untersuchungen über Kartoffelviren. II. Vermessung der Teilchen von drei Stämmen des RattleVirus. Phytopath. Z. 24, 341.

Pirie, N. W. (1957). The anatomy of tobacco mosaic virus. Advanc. Virus Res. 4, 159.

Schachman, H. K. \& Lauffer, M. A. (1949). The hydration size and shape of tobacco mosaic virus. J. Amer, chem. Soc. 71, 536.

Want, J. P. H. van der \& RozendaAl, A. (1948). Electronenmicroscopisch onderzoek van het virus, dat de ratelziekte van der tabak en het stengelbont van de aardappel veroorzaakt. Tijdschr. PlZiekt. 54, 134.

\section{EXPLANATION OF PLATE}

Fig. 1. Enlarged view of a centrifuge tube after centrifuging tobacco rattle virus for $100 \mathrm{~min}$. at 16,500 rev./min. in a density-gradient made from 67, 134 and $200 \mathrm{~g}$./1. sucrose solutions. Note the two opalescent zones.

Fig. 2. Electron micrograph of a purified but unfractionated preparation of tobacco rattle virus. A few particles are seen end-on. $\times 46,200$.

Fig. 3. Electron micrograph of particles from the bottom opalescent zone after two centrifugations in a sucrose density-gradient. $\times 46,200$.

Fig. 4. Electron micrograph of particles from the top opalescent zone after two centrifugations in a sucrose density-gradient. $\times 46,200$.

(Received 27 April 1959) 